\title{
Effect of Drying Methods on Peanut Quality during Storage
}

\author{
Chenling Qu*, Zhuozhen Li, Qiankui Yang, Xueke Wang, and Dianxuan Wang* \\ College of Food Science and Technology, Henan University of Technology, Zhengzhou 450001, CHINA
}

\begin{abstract}
Storage is an important step after peanut harvest and drying. Many factors could affect the peanut quality during storage. The quality change differences of peanut after being dried by solar radiation and at $35^{\circ} \mathrm{C}, 40^{\circ} \mathrm{C}, 45^{\circ} \mathrm{C}, 50^{\circ} \mathrm{C}$ during later storage were investigated, including moisture content (MC) and germination percentage (GP) of peanut kernels, acid value (AV), peroxide value (PV), iodine value (IV), vitamin E (VE) content and fatty acid composition (FAC) of extracted peanut oil. And the impact of four storage conditions, air-room temperature (A-RT), air-low temperature (A-LT), vacuum-room temperature (V-RT) and nitrogen-room temperature (N-RT) on peanut quality after 10 months' storage were also studied in this paper. The results revealed that drying conditions had only a little influence on peanut quality during later storage. Peanut dried by solar radiation was more easily oxidized than that dried under other drying conditions. The effects of storage time were much greater. The GP, AV, PV, VE content and FAC, showed significantly changes along with storage. GP and VE content decreased, AV and PV increased, and some linoleic acid was oxidized to oleic acid after 10 months' storage. In addition, A-LT exhibited best performance in keeping peanut quality than A-RT, V-RT and N-RT, which demonstrated that low temperature was more advantageous for peanut storage than controlled atmosphere. These results above would provide useful information and reference for the peanut storage to apply in food industry.
\end{abstract}

Key words: peanut, storage, drying conditions, low temperature, controlled atmosphere

\section{Introduction}

Peanut (Arachis hypogaea L.) is widely planted and consumed throughout the world and it is an important vegetable protein and oil source ${ }^{1-3)}$. Peanut has high nutritional value, with about $26 \%$ protein, $50 \%$ oil (high content of unsaturated fatty acids, accounting for more than $80 \%$ ), and $3 \%$ fiber, as well as high levels of calcium, thiamine, and niacin, etc. ${ }^{4,5)}$.

Drying and storage are two extremely important steps before peanut processing. Wet peanut needed to be dried to moisture content lower than $10 \%$ w.b. ${ }^{6,7)}$ and then stored in dry environment to prevent mold development and aflatoxin contamination ${ }^{8-10)}$.

In the process of storage, peanut is easy to be oxidized, rancidity, oil-run and produce aflatoxin ${ }^{1,11-13)}$. High peanut seed quality illustrated by high seed vigor and high germination percentage related to the low autoxidation substrates: malondialdehyde (MDA), lipoxygenase (LOX), and high antioxidants: catalase (CAT) and superoxide dismutase $(\mathrm{SOD})^{14)}$. Storage humidity, temperature and the material of package bag were all influence factors of peanut storage.
To maintain peanut quality during storage and reduce economic losses, many researchers have studied the quality changes of peanut under different storage conditions ${ }^{15-17)}$.

Mutegi ${ }^{18}$ found that the moisture content, rancidity, physical damage, and aflatoxin contents of peanuts notably changed at different humidity. Martín ${ }^{19,20)}$ demonstrated that peanut stored at $10^{\circ} \mathrm{C}$ was associated with less quality deterioration than that stored at $25^{\circ} \mathrm{C}$, and peanut qualities (peroxide value, conjugated dienes, free fatty acids, saturated to unsaturated fatty acid ratio, oleic to linoleic ratio, iodine value, roasted peanutty flavor etc.) were better when packed in ethylene vinyl alcohol bags than that in polypropylene ventilated bags except for free fatty acids. $\mathrm{Fu}^{21}$ investigated that the influences of different packing materials on inhibiting aflatoxin production and maintaining the quality of peanuts, and found that peanuts stored in the polyester/aluminum/polyamide/polyethylene and polyamide/polyethylene bags were both better at inhibiting and controlling aflatoxin production. Liu's study ${ }^{22}$ exhibited that storage temperature $\left(15^{\circ} \mathrm{C}, 25^{\circ} \mathrm{C}\right.$, and $\left.35^{\circ} \mathrm{C}\right)$ led to different degrees of lipid oxidation of peanuts. Tempera-

\footnotetext{
*Correspondence to: Chenling Qu, No. 100 of Lianhua Street, Zhengzhou City, Henan Province, People's Republic of CHINA. Dianxuan Wang, No. 100 of Lianhua Street, Zhengzhou City, Henan Province, People's Republic of CHINA E-mail: quchenling82@163.com (CQ), wangdianxuan62@126.com (DW) ORCID ID: https://orcid. org/0000-0001-8337-3758 (CQ) Accepted September 29, 2021 (received for review April 26, 2021) Journal of Oleo Science ISSN 1345-8957 print / ISSN 1347-3352 online http://www.jstage.jst.go.jp/browse/jos/ http://mc.manusriptcentral.com/jjocs

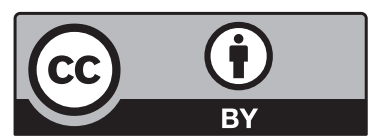


tures could affect peroxide value and malondialdehyde (MDA) content of oil extracted from peanuts significantly, which were the indicators of lipid oxidation degree ${ }^{23)}$.

Besides the quality deterioration of lipid in peanut along with storage, the quality of peanut protein also changed. $\mathrm{Sun}^{24)}$ investigated the molecular functional properties of peanut protein isolate during storage. Extending storage time resulted in a decrease in free sulfhydryl content, fluorescence intensity, surface hydrophobicity and emulsifying properties and an increase in protein particle size. The results also showed the content decline of $\alpha$-helix and $\beta$-sheet, and the content rise of $\beta$-turn and random coil.

In summary, substantial studies have reported that the effects of different storage conditions on the quality of peanuts. However, few works have investigated the effect of different drying conditions on the later storage of peanut. The present study aimed to investigate the quality changes of peanuts during storage after being dried by solar radiation and at $35^{\circ} \mathrm{C}, 40^{\circ} \mathrm{C}, 45^{\circ} \mathrm{C}, 50^{\circ} \mathrm{C}$. The effect of low temperature and controlled atmosphere on peanut storage were also studied.

\section{Materials and Method}

\subsection{Samples}

Tianfu No.3 peanut was planted in April in Weihui County $\left(35.4^{\circ} \mathrm{N}, 114.1^{\circ} \mathrm{E}\right)$, Henan Province, China, and harvested in October. After preliminary drying in the field by the sun, the peanut was picked. And the initial moisture contents of the peanut were tested between $17.7 \%$ and $22.9 \%$. Some of the wet peanuts were spread on the ground and dried by the sun as called solar radiation for 3 days, and some of them were dried by hot air at 35, 40, 45, 50 and $55^{\circ} \mathrm{C}$ for $18 \mathrm{~h}, 14 \mathrm{~h}, 10 \mathrm{~h}, 8 \mathrm{~h}$ and $6 \mathrm{~h}$, respectively until the moisture contents were all below $10 \%$ as mentioned in our previous study ${ }^{25}$. Dried peanuts obtained under different drying conditions were then shelled by a dehusking machine(Yuexin Machinery Factory, Gongyi, China), respectively. And the shelled peanuts were used as samples for storage experiments.

\subsection{Storage conditions}

The shelled peanuts were stored under four conditions as below.

(a) Air-room temperature (A-RT)

The shelled peanuts were put into polyamide and polyethylene (PA/PE) bags, which was $0.16 \mathrm{~mm}$ in thickness, 40 $\mathrm{cm}$ in width and $60 \mathrm{~cm}$ in length. One bag can hold $1500 \mathrm{~g}$ samples. Then the bags with peanut samples were stored at room temperature (Fig. 1).

(b) Air-low temperature (A-LT)

The shelled peanuts were placed in PA/PE bags as described in (a) and stored at quasi-low temperature (less



Fig. 1 Changes of room temperature and quasi-low temperature during storage.

than $20^{\circ} \mathrm{C}$, Fig. 1).

(c) Vacuum-room temperature (V-RT)

The shelled peanuts were first placed in PA/PE bags. Then the air in the bags was drawn using a vacuum packing machine(DZ400, Shanghai Afanlao Machinery Co, Ltd, China) to vacuum degree $90 \mathrm{kPa}$. The vacuum bags were sealed by a plastic film sealing machine(FS-300, Qingye Company, China). And the samples were then stored at room temperature (Fig. 1).

(d) Nitrogen-room temperature (N-RT)

The vacuum bags with shelled peanuts as mentioned in (c) were connected to steel cylinder by syringe needle, rubber tube and pressure reducing valve. And the high-purity nitrogen $(\geq 9.999 \%)$ slowly filled the vacuum bag. Then the pinhole was sealed by the sealing machine. The peanut samples were then stored at room temperature (Fig. 1).

The qualities of the shelled peanuts stored under these different conditions were analyzed after $0,2,4,6,8$ and 10 months of storage, respectively.

\subsection{Moisture content determination}

The moisture content of shelled peanuts was measured according to the American Society of Agricultural and Biological Engineers (ASABE) method S410.2 at $130^{\circ} \mathrm{C}$ for 6 $\mathrm{h}^{26,27)}$.

\subsection{Germination tests}

Based on Chinese National Standard GB/T 5520-2011, samples of 50 shelled peanuts were sowed in wet sand and cultivated at $25^{\circ} \mathrm{C}$ in a climate incubator. The germination percentage was defined as the number of successfully spouted peanuts out of the total number of peanuts after 10 days cultivation. 


\subsection{Peanut oil analysis}

2.5.1 Peanut oil extraction

Soxhlet extraction ${ }^{25)}$, aqueous enzymatic extraction ${ }^{28-30)}$ and thermosonication assisted extraction ${ }^{3)}$ were the common extraction method of peanut oil. In this paper, peanut oil was extracted from the sliced peanut kernels by petroleum ether, and then the petroleum ether was removed with a rotary vacuum evaporator according to $\mathrm{Qu}$ et $a l .{ }^{25)}$ The extracted oil was then used for further chemical analysis.

\subsubsection{Acid value}

The acid values of peanut oil were determined according to the Chinese National Standard GB 5009.229-2016. The extracted oil $(20 \mathrm{~g})$ was placed into conical flask for dissolving the sample in ether-isopropanol solution. Then the solution was titrated with standard $\mathrm{NaOH}$ solution $(0.1 \mathrm{~mol} /$ L) with phenolphthalein as the indicator.

2.5.3 Peroxide value

The peroxide values of peanut oil were measured by the Chinese National Standard GB 5009.227-2016, using 3 g oil from each sample and expressed as millimoles of active oxygen in $1 \mathrm{~kg}$ oil ${ }^{25)}$.

\subsubsection{Iodine value}

Method for iodine values determination of peanut oil followed Chinese National Standard GB/T 5532-2008. Iodine value of peanut oil was expressed in grams of iodine absorbed by $100 \mathrm{~g}_{\mathrm{oil}}{ }^{25)}$.

2.5.5 Vitamin E determination

The contents of vitamin $\mathrm{E}$ for peanut oil were determined using VE test kits (Nanjing Jiancheng Bioengineering Institute, China) according to the manufacturer's protocol, which was on the basis of the reaction of VE and phenanthroline to form a pink complex with $533 \mathrm{~nm}$ absorbance.

2.5.6 Fatty acid composition determination

The composition of fatty acid of peanut oil was determined by gas chromatography (7890 B, Agilent Technologies, USA) with flame ionization detector (GC-FID) according to the Chinese National Standard GB 5009.168-2016 external standard method 7.1. The HP-88 capillary column $(100 \mathrm{~m} \times 0.25 \mathrm{~mm} \times 0.20 \mu \mathrm{m})$ was employed to separate different fatty acids with $1.00 \mathrm{~mL} / \mathrm{min}$ flow rate of carrier gas (nitrogen). The initial temperature was $140^{\circ} \mathrm{C}$ for 5 min, temperature programmed to $240^{\circ} \mathrm{C}$ at $4{ }^{\circ} \mathrm{C} / \mathrm{min}$ and holding at $240^{\circ} \mathrm{C}$ for $20 \mathrm{~min}$. Split ratio was $1: 50$ and FID temperature was $260^{\circ} \mathrm{C}$.

\subsubsection{Data analysis}

Origin (version 9.0) and SPSS (version 21.0) were used to data processing and statistical analysis. The significant difference was determined at the $p<0.05$ level for One way analysis of variance (ANOVA) and Duncan's test.

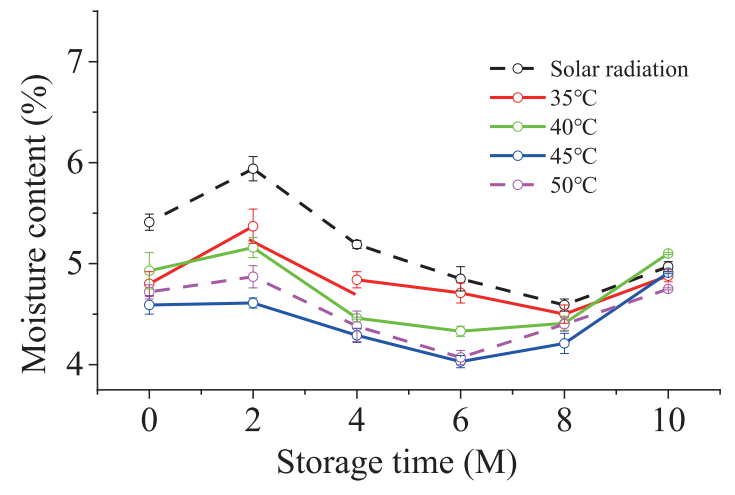

(a)



(b)

Fig. 2 (a) Moisture content and (b) Germination percentage of peanut kernels treated with different drying conditions in A-RT storage condition for 10 months.

\section{Results and Discussion}

\subsection{The effect of different drying conditions on the later storage of peanut}

A-RT was chosen as storage condition to compare the quality change differences of peanut after being dried by solar radiation and at $35^{\circ} \mathrm{C}, 40^{\circ} \mathrm{C}, 45^{\circ} \mathrm{C}, 50^{\circ} \mathrm{C}$ during later storage.

\subsubsection{Moisture content}

Moisture content is one of the most important key factors for peanut storage. The moisture content of peanut at harvest is usually more than $35 \%-45 \%{ }^{6}$. If it is not dried in time, the mold would reproduce and grow fast at appropriate temperature. In case the dried peanut is stored in the humid environment, it is easy to absorb moisture and become moldy. And in severe cases, toxins can also be produced $^{31,32)}$. According to the DB 21/T 2496-2015 peanut storage technical regulations, the safe moisture content of peanut kernel is less than $8 \%$. Salamatullah et $a l .{ }^{33}$ reported that the moisture content of peanut kernels of different harvesting time was determined between $4.47 \%$ and 
$7.93 \%$. In our experiment, the moisture contents of peanut kernels dried by solar radiation and at $35^{\circ} \mathrm{C}, 40^{\circ} \mathrm{C}, 45^{\circ} \mathrm{C}$, $50^{\circ} \mathrm{C}$ during later storage were displayed in Fig. 2 (a). It can be seen that the moisture contents were all between $4.03 \pm 0.06 \%$ and $5.94 \pm 0.12 \%$. Therefore, the moisture contents of peanut kernels were all within the safe range.

\subsubsection{Germination}

Germination percentage (GP) is an important indicator to reflect the vitality of peanuts. The environmental conditions and moisture content could affect peanut germination $^{34)}$. The columns in Fig. 2(b) displayed the effects of different drying conditions on the GP of peanut stored for same period of time in A-RT condition, which showed no significant difference. Therefore, drying conditions (solar radiation and at $35^{\circ} \mathrm{C}, 40^{\circ} \mathrm{C}, 45^{\circ} \mathrm{C}, 50^{\circ} \mathrm{C}$ ) had no influence on the GP of peanut during later storage. The point-line diagram in Fig. 2 (b) exhibited the effect of storage time on GP of peanut. The GP showed significant difference after 10 months' storage, from $95 \pm 3 \%$ at the beginning, to $91 \pm$ $4 \%$ after 8 months and $86 \pm 3 \%$ after 10 months. Hence, storage time had an impact on the germination of peanut.

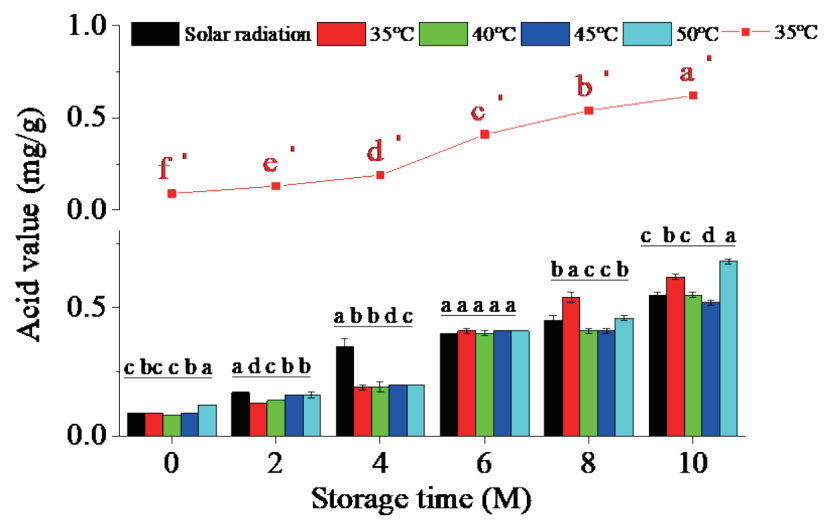

(a)

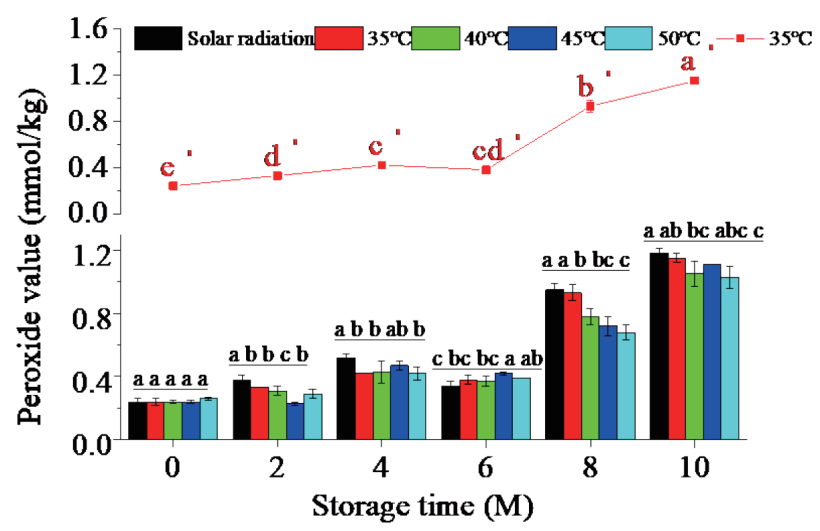

(b)

\subsubsection{Acid value}

Acid value $(\mathrm{AV})$ is a measure of free fatty acid content in oil, and can be used as an indicator of rancidity. It can be seen from Fig. 3(a) that the effect of different drying conditions on $\mathrm{AV}$ during storage. On the whole, the AVs of oil that obtained from peanut dried by solar radiation, at $35^{\circ} \mathrm{C}$ and $50^{\circ} \mathrm{C}$ were a little higher than that obtained at other drying temperatures. This was due to that the moisture contents of peanut dried by solar radiation, at $35^{\circ} \mathrm{C}$ were higher than others during storage(Fig. 2(a)), making the oil easier to hydrolyze. And from our previous study, the $\mathrm{AV}$ of oil extracted from peanuts dried at $50^{\circ} \mathrm{C}(0.124 \mathrm{mg} / \mathrm{g})$ was significantly higher than that from peanut dried by solar radiation $(0.087 \mathrm{mg} / \mathrm{g})$, at $35^{\circ} \mathrm{C}(0.090 \mathrm{mg} / \mathrm{g}), 40^{\circ} \mathrm{C}$ $(0.085 \mathrm{mg} / \mathrm{g})$ and $45^{\circ} \mathrm{C}(0.093 \mathrm{mg} / \mathrm{g})$, showing that higher drying temperature was unfavourable for peanut quality.

Figure 3 (a) displayed that the storage time had an obvious influence on AV. The AV increased along with storage. For instance, the AVs of peanut oil obtained from peanut dried at $35^{\circ} \mathrm{C}$ were $0.09 \pm 0.01 \mathrm{mg} / \mathrm{g}$ before storage, which increased to $0.62 \pm 0.01 \mathrm{mg} / \mathrm{g}$ after 10 months. This



(c)

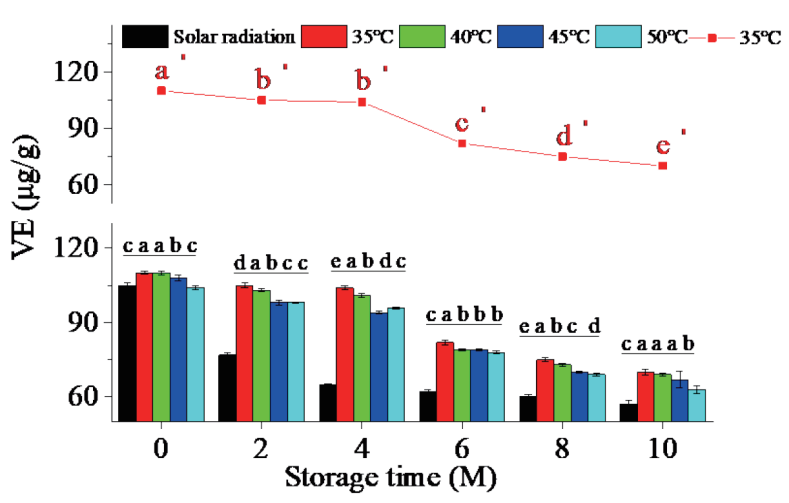

(d)

Fig. 3 (a) Acid value (b) Peroxide value (c) Iodine value (d) VE content of peanut kernels treated with different drying conditions in A-RT storage condition for 10 months. 
was due to the hydrolysis of lipid in peanut during storage, which was in accordance with Martín's research ${ }^{19)}$.

3.1.4 Peroxide value

Peroxide value (PV) is usually used as an indicator of lipid oxidation ${ }^{22,24)}$. This parameter increases while the lipid deterioration advances during grain and food storage ${ }^{25-27)}$. At the same storage period, peanut dried by solar radiation revealed higher PV(Fig. 3(b)). This was due to that in addition to autoxidation, lipoxygenase produced by microorganisms can also catalyze lipid oxidation. Firstly, the drying conditions with higher temperature played the role of sterilization. The longer the storage time, the more obvious the sterilization impact. Secondly, the moisture contents of peanut dried by solar radiation were higher than that of other drying conditions during storage, which were shown in Fig. 3(b). In addition, the PV increased more rapidly after 6 months. For instance, the PVs of the obtained peanut (dried at $35^{\circ} \mathrm{C}$ ) oil were $0.24 \pm 0.02 \mathrm{mmol} / \mathrm{kg}$ before storage, which increased to $0.38 \pm 0.03 \mathrm{mmol} / \mathrm{kg}$ after 6 months, $0.93 \pm 0.05 \mathrm{mmol} / \mathrm{kg}$ after 8 months and $1.15 \pm 0.03$ $\mathrm{mmol} / \mathrm{kg}$ after 10 months. This phenomenon may be owing to the increase of room temperature (Fig. 1)and the acceleration of oxidation rate.

3.1.5 Iodine value

Iodine value (IV) is important in evaluating the quality and shelf life of oils and fats, as it gives a good estimation of their susceptibility to oxidative degradation ${ }^{35)}$. Generally, the higher the IV, the greater the unsaturation degree of the oil, and the higher the content of unsaturated fatty acids in the oil. The IV results were presented in Fig. 3(c), which showed that IVs of peanut oil obtained from peanut dried in different conditions did not significantly changed during storage. And storage time also showed no significant effect on IV.

3.1.6 Vitamin $\mathrm{E}$

Vitamin $\mathrm{E}(\mathrm{VE})$ content could also be used as an indicator of oxidative state for peanut ${ }^{36}$. It stabilizes polyunsaturated fatty acids in membrane lipid bilayers, thus protecting them from lipoxygenase attack and scavenging radicals ${ }^{377}$. Lipid oxidation process results in loss of VE. It can be seen from Fig. 3(d) that VE content of oil extracted from peanut dried by solar radiation was much lower than that dried by hot air at the same storage time. This result was consistent with the PV results. The PV of oil extracted from peanut dried by solar radiation was higher than that of other drying conditions. The PV and the VE content showed negative correlation. Moreover, the VE content reduced more rapidly after 4 months. The VE content of the obtained peanut (dried at $35^{\circ} \mathrm{C}$ ) oil were $110 \pm 0.58 \mu \mathrm{g} / \mathrm{g}$ before storage, which decreased to $104 \pm 0.85 \mu \mathrm{g} / \mathrm{g}$ after 4 months and $70 \pm 1.11 \mu \mathrm{g} / \mathrm{g}$ after 10 months (Fig. $3(\mathrm{~d})$ ).

3.1.7 Fatty acid composition (FAC)

Table 1 showed that there were more than $80 \%$ unsaturated fatty acids in peanut oil, which mainly included oleic acid and linoleic acid. After 10 months' storage, the contents of these fatty acids, C16:0, C18:0, C18:1-9, C18:2-6, C20:0, C20:1-9, C22:0 and C24:0, had no significant difference under different drying conditions (Table 1 ).

However, linoleic acid C18:2-6 decreased from 34.35 \pm $1.21 \%$ to $32.48 \pm 0.20 \%$, and oleic acid C18:1-9 increased from $43.96 \pm 0.06 \%$ to $47.02 \pm 0.50 \%$ after 10 months' storage as suggested by Table 2 . This was due to that the

Table 1 Fatty acid composition of peanut oil extracted from peanut in different drying conditions after 10 months' storage at ART.

\begin{tabular}{|c|c|c|c|c|c|}
\hline \multirow{2}{*}{ FAC $(\%)$} & \multicolumn{5}{|c|}{ Drying temperature $\left({ }^{\circ} \mathrm{C}\right)$} \\
\hline & Solar radiation & 35 & 40 & 45 & 50 \\
\hline Palmitic acid $\mathrm{C} 16: 0$ & $10.88 \pm 0.04^{\mathrm{a}}$ & $10.93 \pm 0.28^{\mathrm{a}}$ & $10.85 \pm 0.08^{\mathrm{a}}$ & $10.94 \pm 0.02^{\mathrm{a}}$ & $10.93 \pm 0.15^{\mathrm{a}}$ \\
\hline Stearic acid C18:0 & $2.92 \pm 0.04^{c}$ & $3.12 \pm 0.14^{\mathrm{ab}}$ & $3.18 \pm 0.02^{\mathrm{a}}$ & $3.02 \pm 0.06^{\mathrm{bc}}$ & $3.14 \pm 0.08^{\mathrm{ab}}$ \\
\hline Oleic acid C18:1-9 & $47.11 \pm 0.30^{\mathrm{a}}$ & $47.02 \pm 0.50^{\mathrm{a}}$ & $46.81 \pm 0.29^{\mathrm{a}}$ & $46.90 \pm 0.18^{\mathrm{a}}$ & $46.82 \pm 0.30^{\mathrm{a}}$ \\
\hline Linoleic acid C18:2-6 & $32.57 \pm 0.13^{\mathrm{b}}$ & $32.48 \pm 0.20^{\mathrm{b}}$ & $32.5 \pm 0.05^{\mathrm{b}}$ & $32.89 \pm 0.21^{\mathrm{a}}$ & $32.47 \pm 0.05^{\mathrm{b}}$ \\
\hline Arachidic acid C20:0 & $1.43 \pm 0.06^{\mathrm{a}}$ & $1.47 \pm 0.10^{\mathrm{a}}$ & $1.51 \pm 0.06^{\mathrm{a}}$ & $1.44 \pm 0.03^{\mathrm{a}}$ & $1.56 \pm 0.09^{\mathrm{a}}$ \\
\hline Gadoleic acid C20:1-9 & $0.90 \pm 0.09^{\mathrm{a}}$ & $0.80 \pm 0.09^{\mathrm{ab}}$ & $0.82 \pm 0.07^{\mathrm{ab}}$ & $0.79 \pm 0.00^{\mathrm{ab}}$ & $0.75 \pm 0.02^{\mathrm{b}}$ \\
\hline Behenic acid C22:0 & $2.68 \pm 0.17^{\mathrm{a}}$ & $2.97 \pm 0.23^{\mathrm{a}}$ & $2.76 \pm 0.07^{\mathrm{a}}$ & $2.60 \pm 0.05^{\mathrm{a}}$ & $2.71 \pm 0.15^{\mathrm{a}}$ \\
\hline Lignoceric acid C24:0 & $1.51 \pm 0.22^{\mathrm{a}}$ & $1.53 \pm 0.20^{\mathrm{a}}$ & $1.58 \pm 0.20^{\mathrm{a}}$ & $1.40 \pm 0.29^{\mathrm{a}}$ & $1.62 \pm 0.18^{\mathrm{a}}$ \\
\hline $\begin{array}{l}\sum \text { SFA (Total amount of } \\
\text { saturated fatty acids) }\end{array}$ & $19.42 \pm 0.44^{\mathrm{a}}$ & $19.71 \pm 0.75^{\mathrm{a}}$ & $19.87 \pm 0.28^{\mathrm{a}}$ & $19.42 \pm 0.39^{\mathrm{a}}$ & $19.96 \pm 0.31^{\mathrm{a}}$ \\
\hline $\begin{array}{l}\sum \text { UFA (Total amount of } \\
\text { unsaturated fatty acids) }\end{array}$ & $80.58 \pm 0.44^{\mathrm{a}}$ & $80.29 \pm 0.75^{\mathrm{a}}$ & $80.13 \pm 0.28^{\mathrm{a}}$ & $80.58 \pm 0.39^{\mathrm{a}}$ & $80.04 \pm 0.31^{\mathrm{a}}$ \\
\hline
\end{tabular}

Data were expressed as means \pm standard deviations. Different superscript letters show a significant difference $(p<$ $0.05)$. 
Table 2 Fatty acid composition of peanut oil extracted from peanut kernel under different storage conditions during drying temperature $35^{\circ} \mathrm{C}$.

\begin{tabular}{|c|c|c|c|c|c|}
\hline \multirow{2}{*}{$\mathrm{FAC}(\%)$} & \multirow{2}{*}{0 months } & \multicolumn{4}{|c|}{ After 10 months storage } \\
\hline & & A-RT & A-LT & V-RT & N-RT \\
\hline Palmitic acid C16:0 & $11.27 \pm 0.05^{\mathrm{a}}$ & $10.93 \pm 0.28^{\mathrm{b}}$ & $10.77 \pm 0.03^{\mathrm{b}}$ & $10.95 \pm 0.12^{b}$ & $10.87 \pm 0.09^{b}$ \\
\hline Stearic acid C18:0 & $2.77 \pm 0.31^{\mathrm{b}}$ & $3.12 \pm 0.14^{\mathrm{ab}}$ & $3.05 \pm 0.08^{\mathrm{ab}}$ & $3.18 \pm 0.14^{\mathrm{a}}$ & $3.09 \pm 0.13^{\mathrm{ab}}$ \\
\hline Oleic acid C18:1-9 & $43.96 \pm 0.06^{\mathrm{c}}$ & $47.02 \pm 0.50^{\mathrm{ab}}$ & $46.80 \pm 0.46^{\mathrm{ab}}$ & $47.34 \pm 0.33^{\mathrm{a}}$ & $46.57 \pm 0.44^{\mathrm{b}}$ \\
\hline Linoleic acid C18:2-6 & $34.35 \pm 1.21^{\mathrm{a}}$ & $32.48 \pm 0.20^{\mathrm{c}}$ & $32.94 \pm 0.26^{\mathrm{b}}$ & $32.39 \pm 0.05^{\mathrm{c}}$ & $33.13 \pm 0.31^{\mathrm{b}}$ \\
\hline Arachidic acid C20:0 & $1.48 \pm 0.22^{\mathrm{a}}$ & $1.47 \pm 0.10^{\mathrm{a}}$ & $1.43 \pm 0.05^{\mathrm{a}}$ & $1.46 \pm 0.02^{\mathrm{a}}$ & $1.51 \pm 0.13^{\mathrm{a}}$ \\
\hline Gadoleic acid C20:1-9 & $1.12 \pm 0.02^{\mathrm{a}}$ & $0.80 \pm 0.09^{\mathrm{b}}$ & $0.91 \pm 0.24^{\mathrm{b}}$ & $0.73 \pm 0.03^{\mathrm{b}}$ & $0.77 \pm 0.01^{\mathrm{b}}$ \\
\hline Behenic acid C22:0 & $2.97 \pm 0.23^{\mathrm{a}}$ & $2.66 \pm 0.16^{\mathrm{ab}}$ & $2.64 \pm 0.21^{\mathrm{ab}}$ & $2.55 \pm 0.18^{\mathrm{b}}$ & $2.69 \pm 0.20^{\mathrm{ab}}$ \\
\hline Lignoceric acid C24:0 & $1.71 \pm 0.31^{\mathrm{a}}$ & $1.53 \pm 0.20^{\mathrm{a}}$ & $1.46 \pm 0.31^{\mathrm{a}}$ & $1.39 \pm 0.38^{\mathrm{a}}$ & $1.37 \pm 0.44^{\mathrm{a}}$ \\
\hline $\begin{array}{l}\sum \text { SFA (Total amount of } \\
\text { saturated fatty acids) }\end{array}$ & $19.16 \pm 0.36^{\mathrm{a}}$ & $19.71 \pm 0.75^{\mathrm{a}}$ & $19.35 \pm 0.50^{\mathrm{a}}$ & $19.53 \pm 0.35^{\mathrm{a}}$ & $19.53 \pm 0.73^{\mathrm{a}}$ \\
\hline $\begin{array}{l}\sum \text { UFA (Total amount of } \\
\text { unsaturated fatty acids) }\end{array}$ & $80.84 \pm 0.36^{\mathrm{a}}$ & $80.29 \pm 0.75^{\mathrm{a}}$ & $80.65 \pm 0.50^{\mathrm{a}}$ & $80.47 \pm 0.35^{\mathrm{a}}$ & $80.47 \pm 0.73^{\mathrm{a}}$ \\
\hline
\end{tabular}

Data were expressed as means \pm standard deviations. Different superscript letters show a significant difference $(p$ $<0.05)$.

unsaturated bonds of linoleic acid were oxidized during storage to form oleic acid.

\subsection{The effect of different storage conditions on peanut quality}

Peanut dried at $35^{\circ} \mathrm{C}$ were dehulled and stored in four different storage conditions (A-RT, A-LT, V-RT, N-RT) for 10 months.

\subsubsection{Moisture content}

The moisture content of peanut kernels before storage was $4.80 \pm 0.12 \%$ (Fig. $4(\mathrm{a})$ ). After 10 months' storage in A-RT, A-LT, V-RT and N-RT conditions, the moisture contents were $4.88 \pm 0.06 \%, 5.24 \pm 0.14 \%, 4.70 \pm 0.05 \%$ and $4.94 \pm 0.07 \%$, respectively (Fig. $4(\mathrm{a})$ ). They were all in the safe moisture range (below $8 \%$ ).

3.2.2 Germination

The changes in the GP of peanut kernels under different storage conditions (A-RT, A-LT, V-RT and N-RT) were investigated. The results were presented in Fig. 4(b). It can be found that the GP decreased from $95 \pm 3 \%$ to $86 \pm 3 \%$ in A-RT storage condition after 10 months' storage, which was lower than that under other storage conditions. The GP of peanut stored in A-LT, V-RT, N-RT conditions showed no significant difference. Therefore, low oxygen concentration and low temperature were the favorable factors to maintain the GP of peanut.

3.2.3 Acid value

The AVs of oil extracted from peanut stored under A-RT, A-LT, V-RT and N-RT conditions were displayed in Fig. 5 (a). The initial $\mathrm{AV}$ of peanut oil (obtained from peanut dried at $35^{\circ} \mathrm{C}$ ) was $0.09 \pm 0.00 \mathrm{mg} / 100 \mathrm{~g}$, which indicated good quality in terms of the degree of lipid hydrolysis. The
$\mathrm{AV}$ increased significantly after 10 months of storage under A-RT, A-LT, V-RT and N-RT storage conditions. Compared with other storage conditions, peanut kernels stored at A-LT had the lowest acid value, $0.45 \pm 0.03 \mathrm{mg} / 100 \mathrm{~g}$. The acid values reached $0.66 \pm 0.02 \mathrm{mg} / 100 \mathrm{~g}$ and $0.71 \pm 0.01$ $\mathrm{mg} / 100 \mathrm{~g}$ in V-RT and N-RT storage conditions, which was a little higher than that in A-RT condition $(0.62 \pm 0.01$ $\mathrm{mg} / 100 \mathrm{~g}$ ). These results illustrated that low temperature could inhibit the hydrolysis of triglycerides in peanuts to produce free fatty acids, which controlled atmosphere could not.

3.2.4 Peroxide value

Considerable variability in PV of oil extracted from peanut (dried at $35^{\circ} \mathrm{C}$ ) was detected under different storage conditions, which was shown in Fig. 5(b). At the beginning of storage, the PV was $0.24 \pm 0.02 \mathrm{mmol} / \mathrm{kg}$. After 10 months' storage, there were significant differences among different storage conditions, varied between $0.64 \pm 0.06$ $\mathrm{mmol} / \mathrm{kg}(\mathrm{L}-\mathrm{RT})$ and $1.15 \pm 0.03 \mathrm{mmol} / \mathrm{kg}(\mathrm{A}-\mathrm{RT})$. The peanut stored under V-RT and N-RT conditions showed lower PVs than that of A-RT storage, which were $0.88 \pm$ $0.05 \mathrm{mmol} / \mathrm{kg}$ and $0.77 \pm 0.04 \mathrm{mmol} / \mathrm{kg}$, respectively. From these data, it can be concluded that temperature and oxygen concentration influenced the PV. And low temperature and controlled atmosphere could retard the oxidation of peanut.

3.2.5 Iodine value

There were no significant difference in IV of peanut oil after 10 months' storage under different storage conditions, which was displayed in Fig. 5(c). This indicated that unsaturation degree of peanut oil under different storage conditions showed no significant difference. 


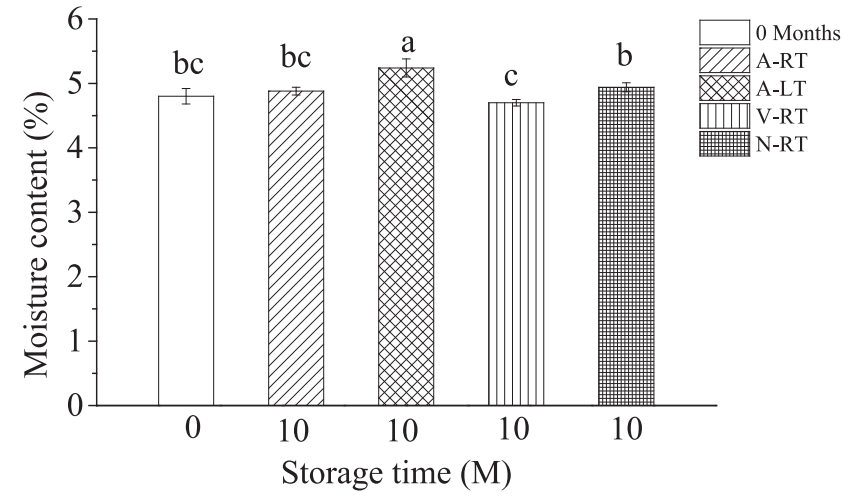

(a)

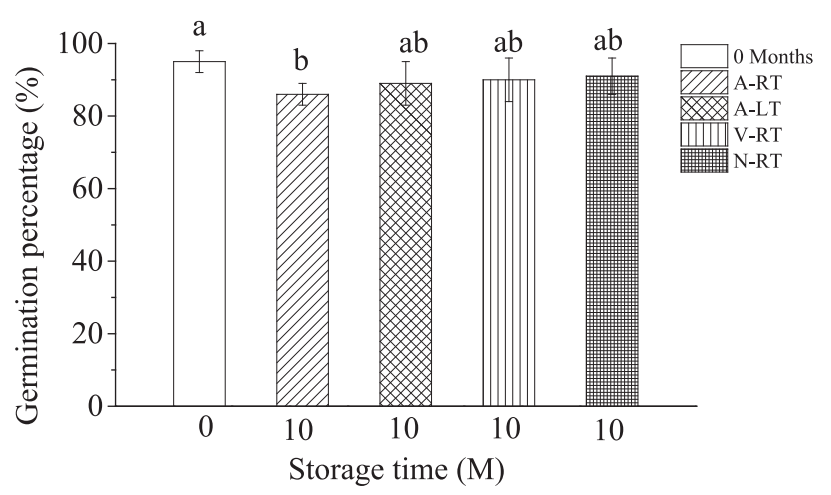

(b)

Fig. 4 Changes of(a) Moisture content and (b) Germination percentage of peanut kernels in four storage conditions, A-RT, A-LT, V-RT and N-RT after 10 months.

\subsubsection{Vitamin E}

Peanut is a rich source of polyphenolic antioxidant compounds, including resveratrol, tocopherol, phytosterol, catechin, epicatechin, and quercetin ${ }^{33)}$. Salamatullah et al. $^{33)}$ reported that gallic acid, 3,4-dihydroxy-benzoic acid, (+ )catechin, and 1,2-dihydroxybenzene were the key phenolic compounds of peanut kernels. The gallic acid content of peanut kernels ranged from $1.36 \mathrm{mg} / \mathrm{L}$ to $2.85 \mathrm{mg} / \mathrm{L}$. The 3,4-dihydroxybenzoic acid content of peanut samples were $1.73 \mathrm{mg} / \mathrm{L}-3.56 \mathrm{mg} / \mathrm{L}$. Additionally, the (+)-catechin content of the peanut kernel samples changed between $2.17 \mathrm{mg} / \mathrm{L}$ and $5.15 \mathrm{mg} / \mathrm{L}$, and the 1,2-dihydroxybenzene content of peanut kernels were $2.67 \mathrm{mg} / \mathrm{L}-5.85 \mathrm{mg} / \mathrm{L}$. In this paper, the results of the VE content of peanut oil during storage were shown in Fig. $5(\mathrm{~d})$. The initial VE contents of peanut oil was $110 \pm 0.58 \mu \mathrm{g} / \mathrm{g}$. After 10 months of storage, VE contents of peanut oil extracted from peanut stored at A-RT, A-LT, V-RT and N-RT were $70 \pm$ $1.11 \mu \mathrm{g} / \mathrm{g}, 84 \pm 1.53 \mu \mathrm{g} / \mathrm{g}, 72 \pm 1.03 \mu \mathrm{g} / \mathrm{g}$ and $81 \pm 1.16 \mu \mathrm{g} / \mathrm{g}$, respectively. Therefore, low temperature showed good performance on protecting the antioxidant system of peanut.

3.2.7 Fatty acid composition

The dominant fatty acids in peanut oil were oleic acid (43.96\%-47.34\%), linoleic acid (32.39\%-34.35\%) and palmitic acid (10.77\%-11.27\%), followed by behenic acid (2.55\%-2.97\%), stearic acid (2.77\%-3.18\%), lignoceric $\operatorname{acid}(1.37 \%-1.71 \%)$, arachidic acid $(1.43 \%-1.51 \%)$ and gadoleic acid (0.73\%-1.12\%), which can be seen in Table 2. It can be seen that there was no significant difference in the fatty acid composition after 10 months' storage under ART, ALT, VRT and NRT storage conditions.

Table 2 also presented the effect of storage time on FAC, The total amount of saturated and unsaturated fatty acids showed no significance after 10 months. However, the FAC of linoleic acid C18:2-6 decreased from $34.35 \%$ to $32.48 \%$ (A-RT), 32.94\% (A-LT), 32.39\% (V-RT), 33.13\% (N-RT) after 10 months' storage. The proportion of oleic acid C18:1-9 increased from $43.96 \%$ to $47.02 \%$ (A-RT), $46.80 \%$ (A-LT) $, 47.34 \%(\mathrm{~V}-\mathrm{RT}), 46.57 \%(\mathrm{~N}-\mathrm{RT})$. That of stearic acid C18:0 increased from $2.77 \%$ to $3.12 \%$ (A-RT), 3.05\% (A-LT), 3.18\% (V-RT), 3.09\% (N-RT) after storage. It demonstrated that the peanut oil was oxidized during peanut storage. At the same time, palmitic acid C16:0 (from $11.27 \%$ to $10.93 \%, 10.77 \%, 10.95 \%, 10.87 \%$ ), gadoleic acid C20:1-9 (from $1.12 \%$ to $0.80 \%, 0.91 \%, 0.73 \%$, $0.77 \%$ ), behenic acid C22:0 (from $2.97 \%$ to $2.66 \%, 2.64 \%$, $2.55 \%, 2.69 \%$ ) and lignoceric acid C24:0 (from $1.71 \%$ to $1.53 \%, 1.46 \%, 1.39 \%, 1.37 \%)$ all showed declined trend. This may be due to the decomposition of the nutrients in peanuts during storage.

\section{Conclusion}

This study demonstrated that drying conditions (solar radiation, $35^{\circ} \mathrm{C}, 40^{\circ} \mathrm{C}, 45^{\circ} \mathrm{C}, 50^{\circ} \mathrm{C}$ ) had only a little impact on peanut quality during later storage. Peanut dried by solar radiation was more easily oxidized than that dried under other drying conditions. The PV and VE content of oil extracted from peanut being dried by solar radiation was significantly different with that of other drying conditions. The effect of storage time on peanut quality was more obvious than that of drying condition. Most indicators, GP, AV, PV, VE content and FAC, showed significantly changes along with storage. For storage conditions, low storage temperature performed best to keep peanut quality than controlled atmosphere storage and A-RT storage. 


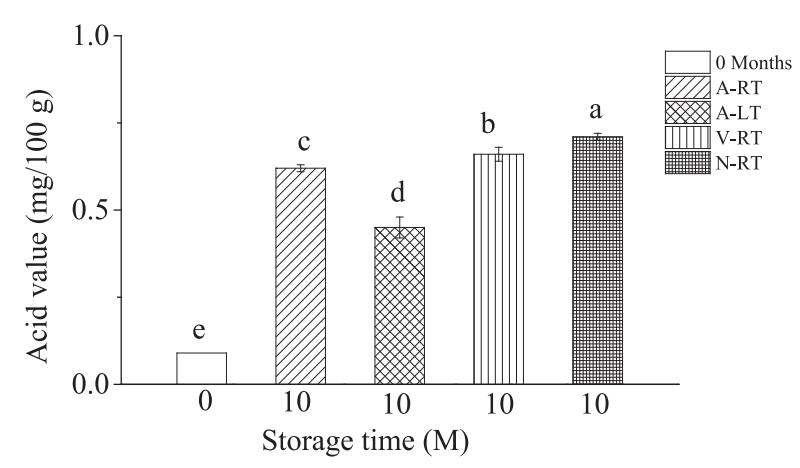

(a)

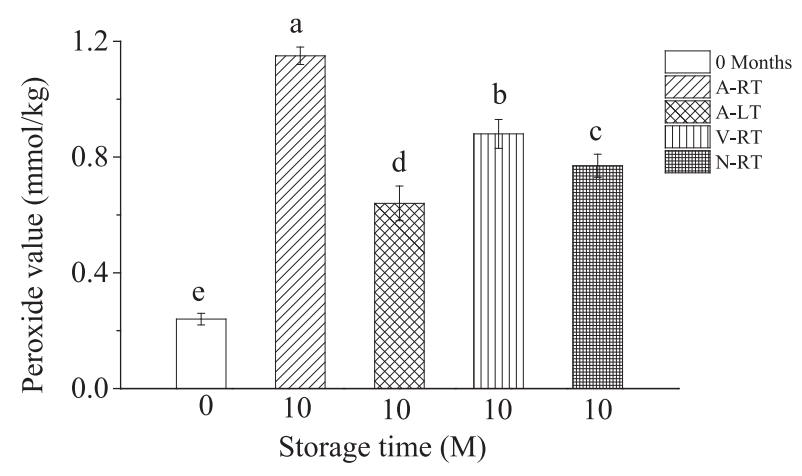

(b)



(c)

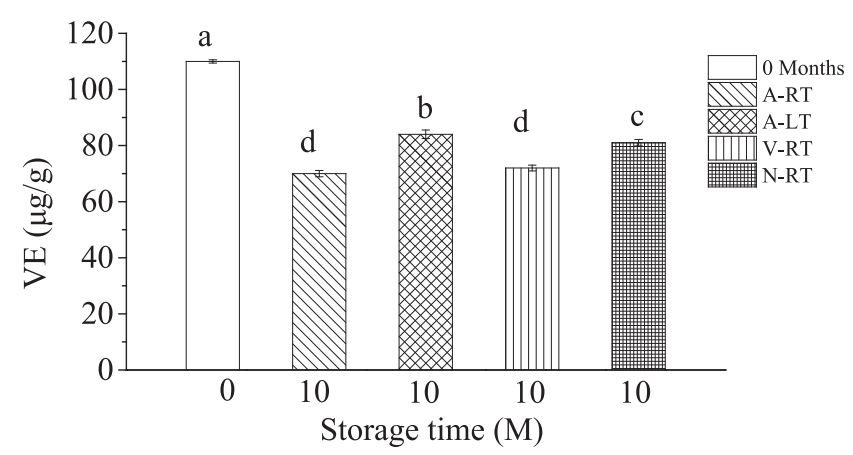

(d)

Fig. 5 Changes of (a)Acid value (b) Peroxide value (c) Iodine value(d)VE content of peanut kernels in four storage conditions, A-RT, A-LT, V-RT and N-RT after 10 months.

\section{Acknowledgements}

This work was supported by grants from China Agriculture Research System of MOF and MARA(CARS-13), the Innovative funds plan of Henan University of Technology (2020ZKCJ14), and the Cultivation Programme for Young Backbone Teachers in Henan University of Technology.

\section{References}

1) Zhang, Y.; Zhang, Y. Effect of lipoxygenase-3 on storage characteristics of peanut seeds. J. Stored Prod. Res. 87, 101589(2020).

2) Zhao, Z.; Chen, F.; Hao, L. Effect of physiochemical factors and peanut varieties on the charge stability of oil bodies extracted by aqueous method. J. Oleo Sci. 68, 297-306 (2019).

3) Ketenoglu, O. Extraction of peanut oil using thermosonication: Modeling and multiobjective optimization of process parameters using Box-Behnken Design. $J$. Oleo Sci. 69, 585-595(2020).

4) Wei, Z.; Wang, J. Detecting internal quality of peanuts during storage using electronic nose responses combined with physicochemical methods. Food Chem.
177, 89-96 (2015).

5) Albergamo, A.; Salvo, A.; Carabetta, S.; Arrigo, S.; Di Sanzo, R. et al. Development of an antioxidant formula based on peanut by-products and effects on sensory properties and aroma stability of fortified peanut snacks during storage. J. Sci. Food. Agr. 101, 638-647 (2020).

6) Sarath, K.L.L.; Goneli, A.L.D.; Filho, C.P.H.; Masetto, T.E.; Oba, G.C. Physiological potential of peanut seeds submitted to drying and storage. J. Seed Sci. 38, 233240 (2016).

7) Lewis, M.A.; Trabelsi, S.; Nelson, S.O. Using microwave sensing to investigate kernel moisture content at the front and back of semitrailers during peanut drying. Appl. Eng. Agric. 33, 611-617(2017).

8) Liu, R.; Lu, M.; Wang, R.; Wang, S.; Chang, M. et al. Degradation of aflatoxin $\mathrm{B}_{1}$ in peanut meal by electron beam irradiation. Int. J. Food Prop. 21, 891- 900 (2018).

9) Passone, M.A.; Rosso, L.C.; Ciancio, A.; Etcheverry, M. Detection and quantification of Aspergillus section Flavi spp. in stored peanuts by real-time PCR of nor1 gene, and effects of storage conditions on aflatoxin production. Int. J. Food Microbiol. 138, 276-281 
(2010).

10) Lavkor, I.; BİçİĊ, M. Aflatoxin occurrence in peanuts grown in osmaniye at harvest, post-harvest, drying and pre-storage periods. J. Agr. Sci-Tarim. Bili. 21, 394-405 (2015).

11) Kazemian-Bazkiaee, F.; Ebrahimi, A.; Hosseini, S.M.; Shojaee-Aliabadi, S.; Farhoodi, M.; Rahmatzadeh, B.; Sheikhi, Z. Evaluating the protective effect of edible coatings on lipid oxidation, fatty acid composition, aflatoxins levels of roasted peanut kernels. J. Food Meas. Charact. 14, 1025-1038(2020).

12) Wei, S.; Huang, J.; Zhang, L.; Sun, Q.; Sun, X. et al. Physicochemical properties and stabilities of crude and purified oil bodies extracted from high oleic peanuts. Eur. J. Lipid Sci. Tech. 122, 1900183 (2020).

13) Torres, A.M.; Barros, G.G.; Palacios, S.A.; Chulze, S.N.; Battilani, P. Review on pre- and post-harvest management of peanuts to minimize aflatoxin contamination. Food Res. Int. 62, 11-19(2014).

14) Jeammuangpuk, P.; Promchote, P.; Duangpatra, J.; Chaisan, T.; Onwimol, D.; Kvien, C.K. Enhancement of Tainan 9 peanut seed storability and germination under low temperature. Int. Eur. J. Agron. 2020, 8813285 (2020).

15) Pereira, A.A.M.; Prestes, F.S.; Silva, A.C.M.; Nascimento M.S. Evaluation of the thermal resistance of Salmonella Typhimurium ATCC 14028 after long-term blanched peanut kernel storage. LWT-Food Sci. Technol. 117, 108701 (2020).

16) Zhang, W.; Lv, Y.; Lv, A.; Wei, S.; Zhang, S. et al. Sub3 inhibits Aspergillus flavus growth by disrupting mitochondrial energy metabolism, and has potential biocontrol during peanut storage. J. Sci. Food Agr. 101, 486-496 (2021).

17) Liu, W.; Zhao, P.; Shi, Y.; Liu, C.; Zheng, L. Rapid determination of peroxide value of peanut oils during storage based on Terahertz spectroscopy. Food Anal. Methods 14, 1269-1277 (2021).

18) Mutegi, C.K.; Wagacha, J.M.; Christie, M.E.; Kimani, J.; Karanja, L. Effect of storage conditions on quality and aflatoxin contamination of peanuts (Arachis hypogaea L.). Int. J. Agric. Sci. 3, 746-758(2013).

19) Martín, M.P.; Asensio, C.M.; Nepote, V.; Grosso, N.R. Improving quality preservation of raw stored under different conditions during a long-term storage. Eur. $J$. lipid Sci. Tech. 120, 1800150 (2018).

20) Martín, M.P.; Nepote, V.; Grosso, N.R. Chemical, sensory, and microbiological stability of stored raw peanuts packaged in polypropylene ventilated bags and high barrier plastic bags. LWT-Food Sci. Technol. 68, 174$182(2016)$.

21) Fu, X.; Xing, S.; Xiong, H.; Min, H.; Zhu, X. et al. Effects of packing materials on storage quality of peanut kernels. Pros One 13, e0190377 (2018).
22) Liu, K.; Liu, Y.; Chen, F. Effect of storage temperature on lipid oxidation and changes in nutrient contents in peanuts. Food Sci. Nutr. 7, 2280-2290 (2019).

23) Nader, J.; Afif, C.; Louka, N. Impact of a novel partial defatting technology on oxidative stability and sensory properties of peanut kernels. Food Chem. 334, 127581 (2021).

24) Sun, X.; Jin, H.; Li, Y.; Feng, H.; Liu, C.; Xu, J. The molecular properties of peanut protein: Impact of temperature, relative humidity and vacuum packaging during storage. Molecules 23, 2618(2018).

25) Qu, C.; Wang, X.; Wang, Z.; Yu, S.; Wang, D. Effect of drying temperatures on the peanut quality during hot air drying. J. Oleo Sci. 69, 403-412 (2020).

26) AOAC. Moisture measurement-peanuts s410.2. American Society of Agricultural and Biological Engineers (2010).

27) Butts, C.L.; Lamb, M.C.; Sorensen, R.B.; Chen, S. Oven drying times for moisture content determination of single peanut kernels. Trans. ASABE 57, 579-584 (2014).

28) Liu, C.; Chen, F.; Niu, R.; Gao, Y. Effects of pretreatment on the yield of peanut oil and protein extracted by aqueous enzymatic extraction and the characteristics of the emulsion. J. Oleo Sci. 69, 1445-1453 (2020).

29) Liu, C.; Hao, L.; Chen, F.; Zhu, T. The mechanism of extraction of peanut protein and oil bodies by enzymatic hydrolysis of cell wall. J. Oleo Sci. 69, 14671479 (2020).

30) Niu, R.; Chen, F.; Zhao, Z.; Xin, Y.; Duan, X.; Wang, B. Effect of papain on the demulsification of peanut oil body emulsion and the corresponding mechanism. $J$. Oleo Sci. 69, 617-625(2020).

31) Gu, S.; Chen, W.; Wang, Z.; Wang, J. Rapid determination of potential aflatoxigenic fungi contamination on peanut kernels during storage by data fusion of HSGC-IMS and fluorescence spectroscopy. Postharvest Biol. Tec. 171, 111361(2021).

32) Lavkor, I.; Var, I.; Saglam, S.; Uckun, O.; Tekin, A.; Savas, O. Presence of some mycotoxins in peanuts from harvest to storage. Legume Res. 42, 862-866 (2019).

33) Salamatullah, A.M.; Alkaltham, M.S.; Özcan, M.M.; Uslu, N.; Hayat, K. Effect of maturing stages on bioactive properties, fatty Acid compositions, and phenolic compounds of peanut (Arachis hypogaea L.) Kernels harvested at different harvest times. J. Oleo Sci. 70, 471-478(2021).

34) Kumar, M.V.; Eevera, T.; Ramesh, D.; Umarani, R. Influence of groundnut seed viability on biodiesel feedstock quality. Ind. Crops Prod. 140, 111697 (2019).

35) Xu, L.; Yu, X.; Liu, L.; Li, M.; Zhang, R. A rapid method for evaluating the edible oil oxidative stability during ambient storage by FTIR spectroscopy using a mesh 
cell. Anal. Methods 8, 5117-5122(2016).

36) Silva, M.P.; Martinez, M.J.; Casini, C.; Grosso, N.R. Tocopherol content, peroxide value and sensory attributes in roasted peanuts during storage. Int. J. Food Sci. Tech. 45, 1499-1504(2010).

37) Holownia, K.I.; Erickson, M.C.; Chinnan, M.S.; Eitenmiller, R.R. Tocopherol losses in peanuts oil during pressure frying of marinated chicken strip coated with edible films. Food Res. Int. 34, 77-80(2001).
CC BY 4.0 (Attribution 4.0 International). This license allows users to share and adapt an article, even commercially, as long as appropriate credit is given. That is, this license lets others copy, distribute, remix, and build upon the Article, even commercially, provided the original source and Authors are credited. 